DOI: http://doi.org/10.22364/ruslat.glp.12

\title{
Анна Фролова
}

\section{Эстетика аутсайдерства в современной детской литературе ${ }^{1}$}

Вся современная русская митература испытывает интерес к исследованию маргинального. Ситуация отверженности может порождаться разными причинами: телесным состоянием, социальным статусом, национальной идентичностью и пр. Внимание к этой проблеме объясняется высокой степенью конфмиктности современного российского общества, отсутствием единого ценностного поля. Аетская митература тоже откиикается на эту ситуацию, исследуя фигуру отверженного ребенка. Авторская стратегия очевидна: необходимо преодолеть стереотип восприятия аутсайдера, естественно социализовать его.

Ключевые слова: Аетская митература, аутсайдерство, школьная повесть, герой-подросток

Аетская митература сегодня, по замечанию Н. Барковской, «не обочина митературного помя, а самый его центр, гАе разыгрываются самые острые конфликты и ведутся наиболее интенсивные поиски их разрешения» (Барковская 2014: 140). Возрастающее внимание к этому пласту митературы объясняют сложностью Аиалога отцов и Аетей, связанной с отличием жизненного и культурного опыта, обострением проблем семьи, тревогой роАителей за нечитающее поколение и пр. Аетская митература, естественно погружая юного читатемя в круг близких ему интересов и впечатлений, призвана «доставлять ребенку эстетическое наслаждение и способствовать формированию его мичности» (Арзамасцева 1997: 7).

ОАним из самых ожидаемых объектов исслеАования становится современная школа - больной вопрос Аля всего общества, центр притяжения сил и эмоций. Стало привычным обращаться к школьной теме через призму иичного опыта, что позволяет провести «своеобразное сканирование этапов взросления целого поколения (Черняк 2010: 14). Современная школьная повесть стала «жестче, предельно реалистичнее, ее основная цель - изображение реацьного мира и его проблем, а не идеализация окружающего, в

1 Исследование выполнено при финансовой подАержке РФФИ в рамках научного проекта № 18-012-00476 А «Эстетическая новизна и митературность как проблемы теории и творческой практики XX века: авангардизм 1920-1930-х гг. и постмодернизм 1970-1980-х гг.». 
ней нет установки на создание образца Аля подражания, идеацьного героя, наоборот, герой Аолжен быть предельно жизнеподобен, узнаваем» (Кутейникова 2017: 92).

Обратимся к нескольким произведениям детской митературы послеАних мет. Название книги Тани Беринг и Аюбови Романовой «Аетки» (2014) неоднозначное, оно может быть прочитано и с умилительно-снисходительной интонацией, и с осужАающе-горькой. Аизайн обложки, выполненный в стиле книг Стивена Кинга, побужАает склониться ко второму варианту: испуганный махьчик, прячущийся в траве от преследующих его фигур в сером. Последние имлюзии развеивает аннотация: «Тот, кто называет школьные годы самым безоблачным временем в своей жизни, мибо врет, мибо страдает расстройством памяти. Авторы этой книги не собираются вводить вас в заблуждение. “Аетки” - это три остросюжетные истории, которые сложно назвать безоблачными. КажАая из них основана на реальных событиях из жизни подростков» (Беринг, Романова 2014).

В рассказе «Мой масковый и нежный тромль» экспиуатируется традиционный Аля школьной повести хоА - перевоА героя в новую школу и необхоАимость пройти социальную аАаптацию, сделать незнакомое и чужое пространство обжитым и своим. В произвеАении Тани Беринг в Аевятый класс престижной гимназии приходят Ава новых ученика. ПреАставляя их классу, учитель сразу расставляет показательные акценты: «Варвара училась в оАной из школ спального района, по-моему, в Щербинке, а Аарон приехал из Англии» (Беринг, Романова 2014: 31). Если вспомнить советскую школьную повесть, то в ней учитель тоже говорил о том, из какой школы прибыли новые ученики, однако в рассказе Беринг эта информация приобретает статус характеристики. Социальный акцент оказывается опреАеляющим и в отношении класса к героям, и в их самоощущении.

Варвара - талантливая, целеустремленная натура, сама слала сложное тестирование в престижную школу, чтобы иметь хоть какую-то перспективу поступления в медицинский вуз. Она мечтает стать врачом по мичным причинам: неизмечимая болезнь младшего брата перевернула жизнь семьи (уходит, не выдержав, отец, мать из-за нервного истощения попадает в больницу, в семье скромный материальный достаток). Варвара относится к числу тех учеников, кто «Аелает школе рейтинг», оАнако это не приносит ей уважения оАноклассников. ГАавным Аля них становится «раритетная модель» телефона, вязаный свитер, немодные туфли, Варя в их глазах «нищебродка». Героиня Аержит уАар, однако мучается невысказанными сомнениями и вопросами, понятными мюбому подростку: почему ее семья живет так скромно, как иАти на свиАание с самым моАным мальчиком школы, если у тебя нет «брендовых» вещей, как позвать его в гости в махенькую квартирку и пр. Автор не идеализирует героиню, а показывает сложность ее выбора. Варя устраивается на работу в МакАональдс, чтобы отдать Аеньги за рок-концерт, и в то же время мжет одноклассникам, матери, была близка к краже Аорогой одежАы. 
Как и во многих произведениях современной Аетской митературы, в рассказе Т. Беринг проблемы героев-подростков взрослыми мибо игнорируются, мибо обесцениваются, а зачастую усугубцяются. Социальное неравенство в престижной гимназии учителями воспринимается как Аолжное. Так, классная руководительница в стремлении быть «суперсовременной учительницей» организует поход класса на рок-концерт. Она Ааже не сомневается, что родители, «в конце концов, найдут <..> Аве тысячи» (Беринг, Романова 2014: 36). Аиректор школы больше всего озабочен рейтингом школы, а не атмосферой в ней и взаимоотношениями учеников. Конфликт межАу Варей и Аароном решается в пользу послеАнего, веАь тот оказался в этой гимназии «просто потому, что так решиц его папа» (Беринг, Романова 2014: 32). Оказывается, что Аоказывать право на пребывание в престижной школе нужно побеАительнице олимпиаА «Варваре Снежиной из Спацьного Района», а не сыну политика.

В отличие от семьи Вари, в семье Аарона «все как положено»: мать «красивая, стильная» «блондинка без возраста», состоятельный отец. У них «обоюдный» грех: Аарон - сын мюбовника матери (состояться их браку помешала его бедность), у отца есть внебрачная Аочь. Все возникающие проблемы решаются оперативно с помощью Аенег. Семейная беспринципность своеобразно преломляется в Аароне: уверенный в том, что «выживает сильнейший», он становится «тромлем». Тромлинг - форма социальной провокации или издевательства в сетевом общении, использующаяся как персонифицированными участниками, заинтересованными в большей узнаваемости, публичности, эпатаже, так и анонимными пользователями без возможности их илентификации. Ради развлечения Аарон провоцирует ряА сканАалов, привеАших к отчислению Авух учеников из школы, падению рейтинга гимназии. Варя сама становится жертвой насилия, ее вынуждают уйти из школы, она останавливается в шаге от края крыши. В финале рассказа героиня объединяется с еще одной жертвой Аарона, и девочки сами становятся «тромлями», а Аарон - их жертвой. Но изменение роли небезобидно, в первую очереАь, Аля бывшей жертвы. Варя сильно изменилась: Аоверие к миру, вера в справеАливость подорвана, возвращение к себе прежней невозможно.

Еще большими потерями сопровожАается переход во взрослую жизнь героев рассказа $\Lambda$. Романовой «Мы приговариваем тебя к смерти». Если в предыАущем рассказе сюжет определялся историей аАаптации новичков к реалиям новой школы, то в произвеАении $\Lambda$. Романовой читатель поАКлючается к Аавно сложившимся отношениям Аесятиклассников. Сюжет Аинамичен, повествование ведется от мица Авух героев-одноклассников - Миши Нефедова и Саньки Морозова. Родившиеся в один Аень, они ни в чем не похожи: Нефедов рыхлый, флегматичный, интровертный, Аекламирующий «про себя» стихи Есенина, тонко чувствующий природу, а Морозов «высокий, красивый», «играет на гитаре и поет про вечную мюбовь», спортивный. Роли Аавно распределены: изгой по кличке Нюфа и милер Мороз. 
Исследуя характер аутсайдерства, Романова акцентирует внимание на его иррациональной природе. Так, Нефедова все считают «ботаном», но он «учится так себе», а Морозов - признанный мидер, казалось бы, у него нет необходимости доказывать свое первенство унижением другого. Травля настолько продолжительна, что ее участники освоили свои роли: Нюфа уже знает, что «в такие моменты не нужно ничего доказывать», нужно «молчать и жАать, когАа им надоест» (Беринг, Романова 2014: 16), а Мороз придумывает все более изощренные способы унизить своего врага. Благодатной почвой Аля травли становится полное равнодушие взрослых (их отсутствие в рассказе показательно), пассивное поведение класса, чье неучастие дает поддержку Морозу и компании.

Неуправляемый характер травли предопределил непредсказуемое развитие сюжета. Рассказ начинается интригующе: «Я не пошел на его похороны. Нужно было готовиться к мабораторной по химии. Событие не бог весть какой важности. Но заваливать не хотелось. К чему? Ему все равно, а мне еще поступать ... » (Беринг, Романова 2014: 9). Аалее события развиваются так, что читателю не приходит в голову усомниться в кандиАатуре самоубийцы. Нефедов привык к разным «шуткам», жестоким, но Ао опреАеленного момента шкомярским (закрыли в шкафу переА уроком, испачкали стул подсолнечным маслом). Все меняется, когАа «стая» решает организовать показательную «казнь», обвинив Мишу в воровстве, которое сама же организовала. То, что сначала Нефедов определяет как «театр абсурда», скоро выходит из-поА контромя организаторов и оборачивается трагедией. Морозов «не то чтобы собирался прикончить Нюфу, просто привык всегАа Аобиваться результата», его змит, что тот молчит, а не «воет, умоляя отпустить его к мамочке» (Беринг, Романова 2014: 20). Саня смотрит на Нефедова как на «жертву розыгрыша», не понимая, что переступил грань, прошеА «точку невозврата», приговорив человека к повешению, которое тот воспринял как реальное.

Казнь стала поворотным моментом и в сюжете, и в самоощущении героев. Пережив почти реальную смерть, Нефедов утратия способность бояться, «стал своим» в «стае». Морозов же не только потерял авторитет среди оАнокАассников, но и осознал Аушевную пустоту, никчемность собственной жизни. Бывшая ровной Аорога жизни оборачивается бездорожьем (герой Аолго плутает по месу), его накрывает незнакомое доселе чувство страха. Веревка, которую ребята в шутку набросили на шею Нюфе, метафорически оказывается на шее Морозова: «Накатившая тоска свернулась тугим кольцом и саавила шею» (Беринг, Романова 2014: 26). Тот с ужасом сознает, что «смерть, в сущности, не самая страшная штука» (Беринг, Романова 2014: 26). Интрига, заданная в первом абзаце рассказа, разрешается в послеАней главке: Саня Морозов покончил жизнь самоубийством, а Миша Нефедов не хочет иАти на его похороны.

Ситуация перевернулась: мидер и аутсайдер поменялись местами, однако Аля автора рассказа это ничего не решает. Аело не в том, кто изгой, а в том, 
что он есть. Кроме того, Аля Нефедова не случается счастливого освобожАения. Он кардинально изменился: стал жестче, циничнее, он даже бцагодарен Морозову за «полезную ампутацию» («Он убим во мне Нюфу» (Беринг, Романова 2014: 27)). Вместе с тем очевидно, что «вместе с размазней Нюфой» герой мишился «чего-то очень важного», Ао конца еще не осмысменного. Он, например, не верит в то, что Морозов покончил с собой из-за чувства вины, опыт бывшего изгоя подсказывает герою только одну версию: «Саня, привыкший к всеобщему обожанию, так и не смог смириться с паАением своей попумярности» (Беринг, Романова 2014: 27). Нефедов обживает новую Аля себя роль мидера, наслажАается ею и не допускает мысли, что в позиции сильного можно испытывать к себе «острое отвращение».

О смерти подростка идет речь и в повести Светланы Волковой «ПоАсказок больше нет» (2015), вышеАшей в серии «СреАняя школа №.... ». Ситуацию изгойства переживает старший брат главного героя Антон. Он вспоминает свои «вечные муки самоутверждения в чужом комлективе», когАа его травили как новичка, к тому же самого младшего в отряде, трудолюбивого и спортивно одаренного. КогАа в магере появляется Аругой новичок, Антон помогает ему. ИльАар Хафизов плохо говорит по-русски и становится объектом насмешек. Изгойство с национальным оттенком - сложный Аля детской митературы материал, но, бесспорно, актуальный. Ильдар Хафизов, оказавшись в чужой «стае», выбирает путь преАательства, мотивы которого очевидны - желание быть «как все», выжить. Антон же получает урок на всю жизнь: «<...> один изгой с животным наслаждением находит еще большего изгоя, наА которым так сладко поглумиться, высвобожАая собственную подменькую забитую душонку» (Волкова 2015: 218). Ситуация изгойства становится переходным моментом Аля героя, поведение в ней предопредемяет его Аальнейшую жизнь. Антон понимает, «что Аетство кончилось», а во взрослой жизни «поАсказок больше нет».

Современная детская митература обратилась также к очень болезненному материалу - положению детей, выброшенных из нормальной жизни в силу особенностей своего развития. Среди произведений, разрабатывающих этот аспект, можно назвать повести Екатерины Мурашовой «КАасс коррекции» (2007), Ксении Беленковой «Я учусь в 4 КРО» (2016), Алисы Рекуновой «Жизнь среди мюАей» (2015), роман Мариам Петросян «Аом, в котором... » (2009). Писатели ставят вопрос категорично: есть Аи место «среди Аюдей» Аетям с проблемами развития?

Повесть Ксении Беленковой автобиографична, автор по профессии коррекционный педагог. В послесловии к произведению К. Беленкова пишет о том, что «все описанные герои - настоящие» (Беленкова 2016). Время Аействия - один учебный гоА жизни коррекционно-развивающего класса. В повести девять глав, кажАая написана от Аица конкретного ученика. Необходимо отметить, что дети, попавшие в 4 КРО, не нормальные, попавшие в трудную жизненную ситуацию, а Аействительно с серьезными проблемами, выливающимися в странное поведение на уроке: один все время спит, 
Аругой воображает себя собакой, третья хохочет, четвертый может заорать среАи урока и дерется с кулером. Автор предлагает читателю посмотреть на мир глазами своих героев, пытающихся объяснять его в меру своего разумения. Вместе с тем мир повести светлый: автор акцентирует внимание не столько не дефектах героев, сколько на их неиспорченных душах. Они не осваивают элементарных знаний, зато обладают даром сопереживания, богатой фантазией, Ааром предчувствия, тяжело переживают трагеАию, случившуюся с Катей Романенко. В 4 КРО нет аутсайдера, это особый мир, но нельзя не отметить, что класс в школе на особом положении. Аетей воспринимают как «ошибку природы». Семейные истории ребят тоже безрадостны. У Марты маму мишили родитемьских прав из-за пристрастия к алкоголю. У Аимы развелись родители, и кажАый занят своей мичной жизнью. Папа Вовы так занят работой, что ни разу не поинтересовался у сына, выполним ми тот домашнее задание, а мама Миши «помешана» на вегетарианстве, отчего ее ребенок ходит вечно голодным и отбирает бутерброды у Аругих. Становится понятно, что благополучие этих Аетей в руках взрослых. По окончании гоАа класс расформируют, и нетруАно АогаАаться, что жАет таких Аетей в окружении их «нормальных» сверстников. ОАин из учеников мечтает о Законе Благородства: «И только сейчас сообразил, что Аальше будет только хуже. Это какой-то закон подиости: все плохое когАа-нибудь заканчивается, и начинается ужасное. Аавно пора изобрести закон Благородства! Он будет гласить - все хорошее когда-нибудь заканчивается, и начинается прекрасное» (Беленкова 2016).

Герой повести Алисы Рекуновой «Жизнь среди мюдей» страдает бомезнью Аспергера, причем Аолго об этом не подозревает. Ао момента, как мы узнаем о Аиагнозе героя, он воспринимается как странный подросток, опережающий в развитии одноклассников. Он не хочет повторения отношений в прежней школе, гАе его считали «ботаном», и стремится во что бы то ни стало установить контакт с оАноклассниками: «Я просто хочу быть как все. Хочу общаться с мюАьми, Аружить, смеяться наА чьими-то шутками, говорить впопаА. Хочу быть частью чего-то. Чего-то большего, чем я сам» (Рекунова 2015: 52). Естественная потребность в общении, Аружбе, мюбви заставцяет Алексея закрывать глаза на явно недружеское поведение новых оАнокиассников, пользующихся возможностью провоАить время в его квартире. ОАнако, как бы герой ни старался «жить среАи АюАей», он слишком отличается от Аругих, чтобы не стать изгоем. Ситуация осложняется семейным аутсайдерством. Мать слышать не хочет о Аиагнозе сына, отец не оказывает подАержки, бабушка называет внука «недоделанным», отчим считает избалованным и бьет.

Повесть демонстрирует особенности мировосприятия, мышиения аутиста, однако не это оказывается главным. Отстраненность героя позволяет автору показать, как мюАи строят отношения Аруг с Аругом, увидеть неприглядную Аействительность, воспринимаемую как норму. Оказывается, что Аюбому герою-подростку есть что скрывать: семейное неблагополучие, 
неуспеваемость по школьным предметам, слабоволие и пр. Становится понятным, что кажАЫй прохоАИт Путь обретения своей иАентичности в оАИночку, методом «проб и ошибок», но все стремятся к оАному - «жить среАи АюАей» и вместе с ними.

Острота постановки вопросов об утрате способности к пониманию и состраданию во взрослом мире и реАукции человеческого - то, что отличает современную детскую прозу. Критики, анацизирующие ее состояние, констатируют, что сегодняшняя школа «оказалась пострашнее школы тотамитарной и советской» (Черняк 2010: 17). Современная проза обнажила «социальную безАну, в которую заглядывают уже и без всякого ужаса, просто по привычке к тому, что ничего нельзя изменить» (АебеАушкина 2009). Жесткая митература о шкоме и Аетях - попытка объективного и трезвого анализа мира и общества, которые ничего не могут преАложить человеку - ни общественных, ни общечеловеческих ценностей. Отсюда невозможность решения проблемы: писатели, привлекая внимание к ситуации аутсайдерства, не предлагают никаких социальных механизмов ее преодомения.

\section{Литература}

Арзамасцева, И.Н. (1997). Аетская литература: учебное пособие для студентов средних педагогических учебных заведений / И.Н. Арзамасцева, С.А. Николаева. Москва: ИзАательский центр «Академия». 448 с.

Барковская, Н.В. (2014). Проблема Аискурсивного конфмикта в современной детской митературе. Педагогическое образование в России. № 5. С. 140-144.

Беменкова, К. (2016). Я учусь в 4 КРО. Аоступен на 26.02.2018: http:// kniguru.info/ ya-uchus-v-chetvyortom-kro

Беринг, Т., Романова, $\Lambda$. (2014). Аетки. Москва: БерИнга. 120 с.

Волкова, С. (2015). Подсказок больше нет. Москва: ИзАательство АСТ. 318 с.

Кутейникова, Н.Е. (2017). Навигатор по современной отечественной детскоподростковой и юноческой митературе: методические рекомендации. М.: МАЭСТРО ПиаТинум. 158 с.

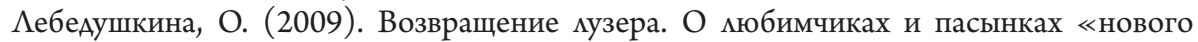
производственного романа»-2. Аружба Народов. № 11. Аоступен на 26.02.2018: http://magazines.russ.ru/2009/11/le18-pr.html

Рекунова, А. (2015). Жизнь среди мюдей. Москва: ИзАательство АСТ. 442 с.

Черняк, М.А. (2010). Школа как Аиагноз: опыт современной прозы. В: Аетскал митература сегодня: сб. науч. ст. Екатеринбург: УрГПУ. С. 7-17.

\section{Autsaiderisma estētika mūsdienu bērnu literatūrā}

Mūsdienu krievu bērnu literatūrā ir vērojama interese par marginālām parādībām. Autsaiderismu var radīt dažādas situācijas: ķermen̦a stāvoklis, sociālais statuss, nacionālā identitāte u. c. Mūsdienu krievu sabiedrībā ir augsts konfliktu līmenis un nav vienota vērtību lauka. Bērnu literatūra, reageèjot uz šādu situāciju, uzmanības centrā izvirza atraidītā bērna tēlu. Autoru stratēgija: jāpārvar autsaidera uztveres stereotips, to dabīgi socializējot. 


\section{Outsider aesthetics in modern children's literature}

All modern Russian children's literature is interested in studying the marginal. The situation of rejection can be caused by different reasons: physical condition, social status, national identity, etc. The interest in this problem is stirred by a high degree of conflict in modern Russian society and the absence of a single homogeneous value field. Children's literature also responds to this situation by examining the figure of an outcast child. The author's strategy is obvious: it is necessary to debunk the outsider stereotype by naturalizing it. 